University of Nebraska - Lincoln

DigitalCommons@University of Nebraska - Lincoln

Faculty Publications: Department of Entomology

Entomology, Department of

$1-2009$

\title{
Registration of 'Mace' Hard Red Winter Wheat
}

Robert A. Graybosch

USDA-ARS, University of Nebraska-Lincoln, bob.graybosch@ars.usda.gov

C. J. Peterson

Oregon State University, Corvallis

P. Stephen Baenziger

University of Nebraska-Lincoln, pbaenziger1@unl.edu

David D. Baltensperger

Texas A\&M University, dbaltensperger@tamu.edu

Lenis Alton Nelson

University of Nebraska-Lincoln, Inelson1@unl.edu

See next page for additional authors

Follow this and additional works at: https://digitalcommons.unl.edu/entomologyfacpub

Part of the Entomology Commons

Graybosch, Robert A.; Peterson, C. J.; Baenziger, P. Stephen; Baltensperger, David D.; Nelson, Lenis Alton; Jin, Y.; Kolmer, J.; Seabourn, B.; French, Roy C.; Hein, Gary L.; Martin, T. J.; Beecher, B.; Schwarzacher, T.; and Heslop-Harrison, P., "Registration of 'Mace' Hard Red Winter Wheat" (2009). Faculty Publications: Department of Entomology. 252.

https://digitalcommons.unl.edu/entomologyfacpub/252

This Article is brought to you for free and open access by the Entomology, Department of at DigitalCommons@University of Nebraska - Lincoln. It has been accepted for inclusion in Faculty Publications: Department of Entomology by an authorized administrator of DigitalCommons@University of Nebraska - Lincoln. 


\section{Authors}

Robert A. Graybosch, C. J. Peterson, P. Stephen Baenziger, David D. Baltensperger, Lenis Alton Nelson, Y. Jin, J. Kolmer, B. Seabourn, Roy C. French, Gary L. Hein, T. J. Martin, B. Beecher, T. Schwarzacher, and P. Heslop-Harrison 


\title{
Registration of 'Mace' Hard Red Winter Wheat
}

\author{
R. A. Graybosch,* C. J. Peterson, P. S. Baenziger, D. D. Baltensperger, L. A. Nelson, \\ Y. Jin, J. Kolmer, B. Seabourn, R. French, G. Hein, T. J. Martin, B. Beecher, \\ T. Schwarzacher, and P. Heslop-Harrison
}

$\boldsymbol{W}$ heat streak mosaic virus (WSMV) is one of the most common, and devastating, diseases impacting wheat (Triticum aestivum L.) production in the western Great Plains of North America. Annual production losses of 5\% have been estimated, although severe local WSMV infection can result in complete crop failure (French and Stenger,

R.A. Graybosch and R. French, USDA-ARS, 314 Biochemistry Hall, East Campus, Univ. of Nebraska, Lincoln, NE 68583; C.J. Peterson, Dep. of Crop and Soil Science, Oregon State Univ., Corvallis, OR 97331; P.S. Baenziger, D.D. Baltensperger, L.A. Nelson, and B. Beecher, Dep. of Agronomy and Horticulture, Univ. of Nebraska, Lincoln, NE 68583; Y. Jin and J. Kolmer, USDA-ARS, Cereal Disease Lab., Univ. of Minnesota, St. Paul, MN 55108; B. Seabourn, USDA-ARS, Hard Winter Wheat Quality Lab., Manhattan, KS 66502; G. Hein, Panhandle Research and Extension Center, Univ. of Nebraska, Scottsbluff, NE 69361; T.J. Martin, Western Kansas Agricultural Research Center, Kansas State Univ., Hays, KS 67601; T. Schwarzacher and P. Heslop-Harrison, Dep. of Biology, Univ. of Leicester, Leicester, UK LE1 7RH; D.D. Baltensperger, current address: Dep. of Soil and Crop Sciences, Texas A\&M Univ., College Station, TX 77843; B. Beecher, current address: USDA-ARS, Washington State Univ., Pullman, WA 99164. Registration by CSSA. Received 18 June 2008. *Corresponding author (bob.graybosch@ars.usda.gov).

Abbreviations: NRPN, Northern Regional Performance Nursery; PCR, polymerase chain reaction; WSBMV, Wheat soilborne mosaic virus; WSMV, Wheat streak mosaic virus.

Published in the Journal of Plant Registrations 3:51-56 (2009). doi: 10.3198/jpr2008.06.0345crc

(C) Crop Science Society of America

677 S. Segoe Rd., Madison, WI 53711 USA

All rights reserved. No part of this periodical may be reproduced or transmitted in any form or by any means, electronic or mechanical, including photocopying, recording, or any information storage and retrieval system, without permission in writing from the publisher. Permission for printing and for reprinting the material contained herein has been obtained by the publisher.
2003). There is little effective WSMV resistance within the primary gene pool of wheat. Resistance of unknown origin is present in the germplasm line CO960293-2 (Haley et al., 2002) and in the cultivar Ron-L (Seifers et al., 2007). This resistance, however, is not effective at temperatures above $18^{\circ} \mathrm{C}$. The resistance gene $W s m-1$, transferred to wheat from intermediate wheatgrass [Thinopyrum intermedium (Host) Barkworth \& DR Dewey] (Friebe et al., 1991), provides more effective resistance at higher temperatures than the resistance gene found in CO960293-2 and Ron-L (Seifers et al., 2006. Transfer of this resistance traces to crosses between wheat and intermediate wheatgrass produced more than three decades ago (Wells et al., 1973, 1982). Subsequent breeding led to the development of wheat lines with Wsm-1 and the potential to prevent major economic losses. However, many derived lines suffered from poor bread-making quality or agronomic properties (Seifers et al., 1995), perhaps due to negative epistatic effects of Wsm1 or closely linked genes. Divis et al. (2006), however, concluded there were no negative effects on grain yield in winter wheats attributable to the presence of $W s m-1$, per se.

From the materials evaluated in the study of Divis et al. (2006), experimental breeding lines with Wsm-1 and with grain yield similar to check cultivars were identified. One such line, subsequently named 'Mace' (Reg. No. CV-1027, PI 651043), was deemed suitable for cultivar release. Mace is a hard red winter wheat cultivar developed cooperatively by the USDA-ARS and the Nebraska Agricultural Experiment Station and released in 2007 by the developing institutions. Mace was released primarily for its field resistance to Wheat streak mosaic virus (WSMV) and adaptation to rainfed and irrigated wheat production systems in Nebraska and adjacent areas in the northern Great Plains. Resistance to WSMV is conditioned by the Wsm-1 gene (Seifers et al., 1995), situated on an introgressed chromosome arm from 
intermediate wheatgrass, Thinopyrum intermedium (Host) Barkworth \& D.R. Dewey [Agropyron intermedium (Horst.) Beauv.] present as a 4DL.4AgS chromosomal translocation (Friebe et al., 1991). Mace was tested under the experimental designation N02Y5117. The name Mace was chosen to honor the memory of Eva Mace Graybosch and her ancestor, Wandle Mace, foreman for the construction of some of the first flour mills in the Nebraska Territory in 1857 and 1858. To our knowledge, Mace is the world's first cultivar to carry Wsm-1.

\section{Methods Early Generation Population Development}

Mace was developed using a modified bulk breeding procedure, followed by reselection for uniformity of field resistance to WSMV. Mace was selected from the cross 'Yuma'//PI 372129/3/CO850034/4/4*Yuma/5/(KS91H184/ Arlin S//KS91HW29/3/NE89526). Yuma (PI 559720, Plant Variety Protection no. 9300009) is a hard red winter wheat cultivar released by Colorado State University in 1991. PI 372129 (= T-57) is a Russian wheat aphid [Diuraphis noxia (Mordvilko)]-resistant landrace from Turkmenistan that carries the Dn4 resistance gene (Saidi and Quick, 1996). CO850034 is a breeding line from the Colorado State University breeding program derived from the cross NS14/ NS603//'Newton'/3/PB835 (Quick et al., 2001). KS91H184 is an experimental line from Kansas State University selected from a random mating population involving CI 17884, the source of resistance to WSMV (Haley et al., 2005). Arlin $S$ is a sister line of the hard white winter wheat 'Arlin', developed and released by Kansas State University. KS91HW29 is a hard white winter wheat breeding line developed by Kansas State University, derived from the cross 2157/entry 164 of the 1984 winter-spring wheat observation nursery distributed by Oregon State University. NE89526 is a hard red winter wheat breeding line developed by the University of Nebraska with the pedigree Lancota S/'Siouxland'//TX79271.

\section{Line Selection and Evaluation}

Mace was derived from a breeding effort to incorporate Wsm-1 into Nebraska-adapted genetic backgrounds. The $\mathrm{F}_{1}$ generation from a number of matings was harvested from single-row plots at Yuma, AZ, in 1994. $\mathrm{F}_{2}$ and $\mathrm{F}_{3}$ generations were grown at Lincoln, NE, as bulk populations in four-row plots, each row $2.4 \mathrm{~m}$ long with $30 \mathrm{~cm}$ between rows. The seeding rate was $54 \mathrm{~kg} \mathrm{ha}^{-1}$. Plots were harvested in the summers of 1995 and 1996, respectively, with a small plot combine (Wintersteiger, Ankeny, IA). In 1996, individual spikes were harvested by hand from the $\mathrm{F}_{3}$ bulk populations and used to seed single-plant-progeny-derived $\mathrm{F}_{4}$ head (spike) rows. Head row selections were planted as single rows in a four-row set $0.9 \mathrm{~m}$ long with $30 \mathrm{~cm}$ between rows, using a Hege head-row planter (Wintersteiger, Colwich KS). In September 1998, 120 head rows deemed possible carriers of Wsm-1 (based on pedigree) were advanced to an unreplicated $\mathrm{F}_{5}$ observation nursery with replicated check cultivars ('Arapahoe' [PI 518591], 'Scout 66' [CItr 13996], 'Alliance'
[PI 573096], 'Tomahawk' [Agripro BioSciences], 'Ike' [PI 574488], and 'Redland' [PI 502907]) included. Experimental breeding lines KS95H102, KS96HW10-1, and KS96HW10-3, also carriers of Wsm-1, were included. The two center rows of each plot were mechanically inoculated with WSMV shortly after emergence, as per Divis et al. (2006).

In summer 1999, entries were scored as resistant or susceptible to WSMV based on the degree of stunting and leaf mottling. The score was bimodal; lines were recorded as resistant or susceptible. Resistant lines showed no plant stunting or leaf mottling. Only six entries appeared to carry resistance, and all six were heterogeneous for the trait. Ninety-six heads were selected from each putative heterogeneous line, and threshed individually. Seed from heads was divided and planted in paired 1-m rows at Lincoln, NE, in September 1999. Susceptible (Tomahawk) and resistant (KS95H102) controls were distributed every 5th and 12th rows, respectively, among the paired rows. One row of each pair was mechanically inoculated with WSMV after emergence. In spring 2000, lines were scored as resistant or susceptible based on visual symptoms (yellow-green mottling of leaves and plant stunting). Resistant rows were harvested and reseeded at Hays, KS, in autumn 2001 to verify these phenotypic scores. Lines, along with resistant and susceptible checks, were planted in unreplicated rows, $1 \mathrm{~m}$ in length. Plants were infected with naturally occurring WSMV by native wheat curl mites (Aceria tosichella Keifer) reared on early-planted wheat. In spring 2002, the lines were rated as resistant or susceptible, again using a bimodal score. Resistance in selected lines was reverified using a similar approach at Scottsbluff, NE, during the 2004 to 2007 crop years. Mace was selected from this group of resistant lines. In 2004, 2006, and 2007, resistance to WSMV also was assessed at Scottsbluff by assignment of stunting scores (0-100 scale, with $100=$ no stunting of plant growth) and acquisition of SPAD values as measured from flag leaves using a SPAD-502 chlorophyll meter (Minolta Camera Co., Japan). Higher SPAD readings indicate greener tissue and a lack of WSMV symptoms.

Agronomic evaluation commenced in 2002 and 2003, when Mace and 29 additional WSMV resistant lines of similar origin were entered in preliminary and advanced yield trials at multiple locations in Nebraska. The widely grown Nebraska cultivar Millennium (PI 613099) was included as a control. On the basis of agronomic performance, Mace was advanced for further testing in the USDA-ARS-coordinated Northern Regional Performance Nursery (NRPN) in 2004 and 2005, and in the Nebraska State-Wide Small Grains Variety Test in 2005 to 2007.

\section{Seed Purification and Increase}

Seed purification of Mace began in the 2005 crop year using visual identification and manual removal of variants (primarily tall and red-chaffed off-types) from bulk seed increases grown under rainfed conditions at Mead, NE. Seed harvested from the advanced yield trials at Lincoln, $\mathrm{NE}$, in 2004 was planted in an unreplicated strip plot (80 $\mathrm{m}^{2}$ ) in autumn 2004. At harvest maturity, 300 individual spikes were hand-harvested and threshed. In autumn 2005, 
the spike selections were used to seed $3002.5-\mathrm{m}$ unreplicated rows at Yuma, AZ. Visual inspection of the Yuma plantings was used to remove variants $(10-15 \mathrm{~cm}$ taller in height). In autumn 2006, $\mathrm{F}_{12}$ seed harvested from Yuma was planted at Mead, NE, in a Breeder seed increase block (approximately $0.2 \mathrm{ha}$ ) and rogued again to remove tall variants. In 2007, a Foundation seed increase was planted by the University of Nebraska Foundation Seed Division. Mace has been stable and uniform since 2006. Up to 1\% (10:1000) variant plants (10-15 cm taller) may be encountered in subsequent generations.

\section{Evaluation of Disease and Insect Reactions}

Mace was evaluated for resistance to stem rust (caused by Puccinia graminis Pers.:Pers f. sp. tritici Eriks. \& E. Henn.) and leaf rust (Puccinia triticina $[=P$. recondita Roberge ex Desmaz. f. sp. tritici]) as an entry in the 2004 and 2005 NRPN evaluated by the USDA-ARS Cereal Disease Laboratory, St. Paul, MN. Seven stem rust races from the United States, MCCF, QFCS, QTHJ, RCRS, RKQQ, TMPK, and TTTT, were used in seedling evaluations. Seedling plants were inoculated 7 to $9 \mathrm{~d}$ after planting. Disease assessment was made $14 \mathrm{~d}$ postinoculation following an infection type scale described by Stakman et al. (1962). Infection types $0, ;, 1,2$, or combinations thereof were considered lowinfection types indicating resistance, and infection types 3 and 4 were considered high infection types indicating susceptibility. Mace was also evaluated with race TTKS (syn. Ug99) at the seedling stage.

Stem rust testing of adult plants was conducted by inoculating field plots with a bulk of stem rust races (MCCF, QFCS, QTHJ, RCRS, RKQQ, and TMPK) on the St. Paul Campus, University of Minnesota. Test entries were planted into 2-m row plots, perpendicular to a spreader row planted with a mixture of stem rust susceptible cultivars Red Chief and McNair 701. Plant response to stem rust infection at the adult plant stage was termed "infection response." Primarily on the basis of the size of the pustules and associated necrosis/chlorosis, infection responses were classified into four discrete categories: R, resistant; MR, moderately resistant; MS, moderately susceptible; and S, susceptible (Roelfs et al., 1992). Stem rust severity was assessed following the modified Cobb scale (Peterson et al., 1948). Entries were evaluated for infection responses and stem rust severity two to three times between heading and plant maturity. The infection responses and stem rust severity at the soft dough stage of plant growth were used to represent the final disease scores. Mace also was tested in the 2006 Kenyan stem rust nursery, coordinated by USDA-ARS and Centro Internacional de Mejoramiento de Maíz y Trigo (CIMMYT).

Responses to leaf rust infection also were evaluated at the Cereal Disease Laboratory, in a manner similar to the procedures used for stem rust evaluations. In 2004, seedlings of Mace were tested against the following races: CBMT, MCDS, MBDS, MHDS, MCRK, THBJ, and TNRJ. In 2005, seedling reactions were determined using races $\mathrm{KDBG}$, MCDS, TCTD, TNRJ, THBJ, MFBJ, and MJBJ and a bulk of all races combined. Field reactions to the race bulk were obtained in 2005 only.
Reactions to stripe rust (Puccinia striiformis Westend.), Hessian fly [Mayetiola destructor (Say)], Russian wheat aphid [(Diuraphis noxia (Kurdjumov)], greenbug (Schizaphis graminum Rondani), and Wheat soilborne mosaic virus (WSBMV) were obtained either from field plantings in Nebraska during agronomic evaluations or as part of routine testing conducted by cooperators of the USDA-ARS coordinated NRPN.

\section{Genetic Analyses}

DNA polymerase chain reactions (PCRs), using primers STSJ15L and STSJ15R, were used to confirm the presence of Wsm-1. Reaction conditions were as per Talbert et al. (1996), except the annealing temperature was increased to $60^{\circ} \mathrm{C}$. Primers P1 and P2 (Li et al., 2005) also were used to verify the presence of DNA derived from Thinopyrum genomes (Li et al., 2005). Genomic in situ hybridization was used to verify the presence of the 4DL.4AgS wheatintermediate wheatgrass chromosomal translocation. All procedures were as per Schwarzacher and Heslop-Harrison (2000). Genomic DNA was obtained from the intermediate wheatgrass cultivar Haymaker (Vogel et al., 2005) and labeled with biotin. Probe dpTA1, specific for D-genome chromosomes (Vershinin et al., 1994), was labeled with digoxygenin and used to identify the chromosomal location of the intermediate wheatgrass DNA. Blocking DNA was from the wheat landrace Chinese Spring. Metaphase chromosome spreads were prepared from root tips. Markers Sr24\#12 and Sr24\#50 (Mago et al., 2005) were used to test for the presence of the stem rust resistance gene $S r 24$, as the results from seedling testing were difficult to interpret.

\section{End-Use Quality Analyses}

Grain samples from the 2004 and 2005 NRPNs (see below) were analyzed for milling and bread-baking properties (using AACC approved methods; American Association of Cereal Chemists, 2000) at the USDA-ARS Hard Winter Wheat Quality Laboratory in Manhattan, KS. Quality of hard winter wheats often is negatively impacted by the presence of chromosome arm 1RS from rye (Secale cereale L.) (Graybosch, 2001). DNA markers SCM9F and SCM9R (Nagy et al., 2003) were used to test for its presence. High-molecular-weight glutenin subunits, which act either as positive or negative determinants of dough quality, were assayed and scored as per Payne and Lawrence (1983).

\section{Statistical Analyses}

All statistical analyses were accomplished using SAS Version 9.1 (SAS Institute, Cary, NC). A general linear model was used. For grain yield, sample means were calculated both within and across locations. However, only acrosslocation means are reported herein. Quality evaluations (see below) were conducted using samples from the 2003 and 2004 USDA-ARS coordinated NRPNs. Samples were obtained by compositing grain from a minimum of three locations within each of the following wheat production zones (Peterson, 1992): North Central Plains; Northern High Plains and Northern Plains. Quality attributes of Mace were compared with those of the check cultivars Nuplains, 
Nekota, and Harding. Sample means were obtained across years and compared via computation of the LSD (0.05). Composite samples from each year-production zone combination served as sample replications.

\section{Characteristics Agronomic and Botanical Description}

Mace is an awned, white-glumed semidwarf hard red winter wheat. Based on data from 38 rainfed Nebraska environments over the 2005 to 2007 harvest seasons, mature plant height of Mace is $79 \mathrm{~cm}, 9 \mathrm{~cm}$ shorter than Millennium. Lodging resistance is good, and similar to '2137' under both rainfed and irrigated conditions. Average heading date of Mace in Nebraska, over the 2005 to 2007 crop years was $121 \mathrm{~d}$ after 1 January, $1 \mathrm{~d}$ later than Millennium. Field appearance of Mace is most similar to the hard white winter wheat 'Antelope'. The juvenile plant growth form is erect, seedling and stem anthocyanin is absent, anther color is yellow, foliage is green, and the stem is hollow. Peduncle length of field-grown (2007) samples averaged $15.7 \mathrm{~cm}$. Results from genomic in situ hybridization indicate that Mace carries a 4DL.4AgS wheat-intermediate wheatgrass chromosomal translocation. In DNA PCRs using primers STSJ15L and STSJ15R, Mace produces a 420-bp PCR product, indicative of the presence of $W s m-1$. In PCR reactions with primer pair P1 and P2, Mace produces a 277-bp product indicative of the presence of DNA from Thinopyrum.

\section{Disease and Insect Resistance}

During the course of its selection and development, Mace consistently demonstrated a lack of symptoms to mechanical and vector-borne WSMV infections (Fig. 1). Resistance is demonstrated by lack of typical symptoms of spring leaf yellowing following fall infections and by resistance to plant stunting, the maintenance of green flag leafs, as evidenced by high SPAD (chlorophyll content) readings, and the lack of significant grain yield loss under viral infection (Table 1).
Table 1. Response of hard red winter wheat cultivar Mace and control cultivars to field infection by Wheat streak mosaic virus (WSMV), Scottsbluff, NE. Data are means from three growing seasons, 2004, 2006, and 2007.

\begin{tabular}{lccc}
\hline \multicolumn{1}{c}{ Cultivar } & Stunting $^{\dagger}$ & SPAD readings & Yield $^{*}$ \\
\hline & & & $\mathrm{kg} \mathrm{ha}^{-1}$ \\
Mace & 81 & 39 & 2665 \\
Jagalene & 33 & 33 & 1130 \\
Millennium & 36 & 26 & 854 \\
Wesley & 34 & 26 & 706 \\
Tomahawk & 19 & 12 & 354 \\
LSD $_{0.05}$ & 18 & 6 & 495 \\
\hline
\end{tabular}

tStunting scores range from 0-100, with $100=$ no stunting of plant growth

¥SPAD values as measured from flag leaves using a SPAD-502 chlorophyll meter (Minolta Camera Co., Japan). Higher SPAD readings indicate greener tissue and lack of WSMV symptoms.

Mace was resistant to the wheat stem rust races TTTT, TPMK, QTHJ, QFCS, RCRS, and RKQQ in seedling tests and resistant to moderately resistant to a bulk of these races in field tests conduced in St. Paul, MN. In field tests in Kenya in 2006, Mace was rated as highly resistant to stem rust infection by race Ug99 (or TTKSK). It was resistant to race TTKSK in seedling tests. The identity of the resistance gene effective against Ug99 is unknown. In PCR reactions using primers Sr24\#12 and Sr24\#50, Mace produced no products, while control samples produced the expected 500- and 200-bp respective products of wheats carrying Sr24, the most likely resistance gene conditioning these observed phenotypes. Resistance derived from rye also could explain these results, but PCR tests for the presence of rye chromosome arm 1RS also were negative. Control PCR using Mace-derived DNA samples and primers to the wheat $w x$ locus were positive, indicating the negative results with the Sr24 and 1RS primers did not arise from degraded DNA samples.

Mace showed uniform resistance only to leaf rust race MJBJ. Based on this response, it is postulated to carry the resistance gene $L r 14 a$ which is ineffective to most current races of leaf rust in the Great Plains. It is moderately resistant to Great Plains races of stripe rust but susceptible to Hessian fly, Russian wheat aphid, and greenbug. As noted above, Mace is resistant to field and artificial inoculations of WSMV and is moderately resistant to WSBMV. Documentation of disease responses of Mace (N02Y5117) is available at the Website of the USDA-ARS-coordinated Hard Winter Wheat Regional Nursery Program (http://www.ars.usda.gov/Research/ docs.htm?docid=11932).

\section{Field Performance}

Mace was evaluated in preliminary and advanced trials in Nebraska, in the USDAARS NRPN in 2004 (15 environments) and 2005 (17 environments) and in the University of Nebraska Small Grains Variety test in 2005 to 2007. In preliminary yield trials in
Figure 1. Field resistance of hard red winter wheat cultivar Mace to Wheat streak mosaic virus, Scottsbluff, NE, 2005. 
2002, and advanced trials in 2003, respective grain yields of Mace were 2934 and $3949 \mathrm{~kg} \mathrm{ha}^{-1}$, not significantly different than those of the check cultivar Millennium (3042 and $4482 \mathrm{~kg} \mathrm{ha}^{-1}$, respectively) (Table 2). One preliminary trial in 2002, located at Sidney, NE, was subjected to a natural and uniform infestation by WSMV. Under these conditions, grain yield of Mace was $2333 \mathrm{~kg} \mathrm{ha}^{-1}$, significantly higher than that of the moderately tolerant cultivar Millennium (1923 $\mathrm{kg} \mathrm{ha}^{-1}$ ) and twice that of the highly susceptible cultivars Tomahawk (1190 kg ha-1) and 'Wesley' (1062 ha-1). In USDA-ARS coordinated regional trials (NRPN), grain yield of Mace equaled that of the check cultivar Harding in 2004 and was significantly greater in 2005 (Table 2). In both rainfed and irrigated University of Nebraska small grains variety trials in the years 2005 to 2007, grain yield of Mace did not differ significantly from that of the check cultivar Millennium (Table 2).

\section{End-Use Quality}

End-use quality evaluations of Mace (Table 3) were conducted by the USDA-ARS Hard Winter Wheat Quality Laboratory, Manhattan, KS, on samples obtained from the 2004 and 2005 NRPN, composited by agroecological production zone. Six samples were evaluated from this 2 -yr period. Mace displayed significantly lower flour ash contents and significantly longer mixograph and bake mix times, than the three check cultivars. Mean mixograph tolerance score of Mace was significantly higher than those of Nuplains and Nekota and equal to that of Harding. Few other differences (Table 3) were noted. Mace carries the high-molecular-weight glutenin subunits 1 , $7+9$, and $5+10$, encoded by the respective alleles $G l u-A 1 a$, Glu-B1c, and Glu-D1d. (Payne and Lawrence, 1983). Rye chromosome arm 1RS is lacking.

\section{Availability}

The Nebraska Foundation Seed Division, Department of Agronomy and Horticulture, University of NebraskaLincoln, Lincoln, NE 68583 will have foundation seed available to qualified certified seed enterprises in 2008. The seed classes will be Breeder, Foundation, Registered, and Certified. Mace has been submitted for plant variety protection under P.L. 10577 with the certification option. A research and development fee will be assessed on all certified seed sales. Small quantities of seed for research purposes may be obtained from the corresponding author. A seed sample has been deposited in USDAARS National Center for Genetic Resources Preservation and in the USDA-ARS National Small Grains Collection, Aberdeen, ID, where seed is freely available to interested researchers.

\section{Acknowledgments}

Financial support of the Nebraska Wheat Board is gratefully acknowledged. Genomic in situ hybridization and PCR experiments were conducted with financial support of a Research Fellowship to the corresponding author from the OECD. Technical assistance of Lori Divis, Vern Hansen, Greg Dorn, Mitch Montgomery, and Chris Hoagland gratefully is acknowledged.

Table 2. Summary of grain yield data for hard red winter wheat cultivar Mace compared with check cultivars evaluated in 90 environments from 2002 to 2007.

\begin{tabular}{|c|c|c|c|c|c|}
\hline Experiment & No. of Environments & Year(s) & Check & Mace yield & Check yield \\
\hline & & & & \multicolumn{2}{|c|}{$\mathrm{kg} \mathrm{ha}^{-1}$} \\
\hline Preliminary & 6 & 2002 & Millennium & $2934 \mathrm{a}^{\dagger}$ & $3042 a$ \\
\hline Advanced & 4 & 2003 & Millennium & $3949 a$ & $4482 a$ \\
\hline $\mathrm{NRPN}^{\ddagger}$ & 15 & 2004 & Harding & $4517 a$ & $4553 a$ \\
\hline NRPN & 17 & 2005 & Harding & $3726 a$ & $2776 b$ \\
\hline$N E^{\S}$ rainfed & 37 & $2005-2007$ & Millennium & $3539 a$ & $3843 a$ \\
\hline NE irrigated & 11 & $2005-2007$ & Millennium & $5777 a$ & $5582 a$ \\
\hline
\end{tabular}

${ }^{\dagger}$ Means followed by the same letter with a row did not differ significantly at $p=0.05$.

*USDA-ARS coordinated Northern Regional Performance Nursery (http://www.ars.usda.gov/Research/docs.htm?docid=11932)

§University of Nebraska Small Grains Variety Trials (http://varietytest.unl.edu/winterwheat.html).

Table 3. End-use quality attributes of hard red winter wheat cultivar Mace compared with check cultivars from the 2004 and 2005 USDA-ARS Northern Regional Performance Nurseries.

\begin{tabular}{|c|c|c|c|c|c|c|c|c|c|c|c|c|c|}
\hline Cultivar & $\begin{array}{c}\text { Kernel } \\
\text { wt. }\end{array}$ & $\begin{array}{c}\text { Grain } \\
\text { hardness } \\
\text { score }\end{array}$ & $\begin{array}{c}\text { Grain } \\
\text { protein } \\
\text { conc. }^{\dagger}\end{array}$ & $\begin{array}{l}\text { Flour } \\
\text { milling } \\
\text { yield }\end{array}$ & $\begin{array}{c}\text { Flour } \\
\text { ash } \\
\text { content }\end{array}$ & $\begin{array}{c}\text { Flour } \\
\text { protein } \\
\text { conc. }\end{array}$ & $\begin{array}{c}\text { Mix. } \\
\text { water } \\
\text { abs. }{ }^{+}\end{array}$ & $\begin{array}{l}\text { Mix. } \\
\text { time }\end{array}$ & $\begin{array}{c}\text { Mix. } \\
\text { tolerance }\end{array}$ & $\begin{array}{c}\text { Bake } \\
\text { water } \\
\text { abs. }{ }^{\dagger}\end{array}$ & $\begin{array}{c}\text { Bake } \\
\text { mix } \\
\text { time }\end{array}$ & $\begin{array}{c}\text { Crumb } \\
\text { score }\end{array}$ & $\begin{array}{l}\text { Loaf } \\
\text { vol. }\end{array}$ \\
\hline \multicolumn{8}{|c|}{$\mathrm{g} \mathrm{kg}^{-1} \longrightarrow$} & $\min$ & $0-6$ & $\mathrm{~g} \mathrm{~kg}^{-1}$ & $\min$ & $0-5$ & $\mathrm{~mL}$ \\
\hline Harding & 28.4 & 62.4 & 145 & 616 & 4.27 & 123 & 637 & 3.7 & 4 & 632 & 4.6 & 3 & 905 \\
\hline Nuplains & 27.7 & 70.0 & 139 & 660 & 4.07 & 120 & 631 & 2.7 & 3 & 615 & 3.8 & 4 & 916 \\
\hline Nekota & 31.5 & 61.7 & 135 & 652 & 3.75 & 116 & 626 & 3.2 & 3 & 626 & 4.2 & 3 & 884 \\
\hline Mace & 26.5 & 61.5 & 132 & 631 & 3.50 & 115 & 625 & 4.6 & 5 & 635 & 6.2 & 3 & 844 \\
\hline $\mathrm{LSD}_{0.05}$ & 3.0 & ns & ns & 20 & 0.50 & ns & ns & 0.5 & 1.0 & $\mathrm{~ns}$ & 1.0 & ns & $\mathrm{ns}$ \\
\hline
\end{tabular}

${ }^{\dagger}$ conc., concentration; Mix., mixograph; abs., absorption. 


\section{References}

American Association of Cereal Chemists. 2000. Approved methods of the AACC. 10th ed. AACC, St. Paul, MN.

Divis, L.A., R.A. Graybosch, C.J. Peterson, P.S. Baenziger, G.L. Hein, B.B. Beecher, and T.J. Martin. 2006. Agronomic and quality effects in winter wheat of a gene conditioning resistance to wheat streak mosaic virus. Euphytica 152:41-49.

Friebe, B., Y. Mukai, H.S. Dhaliwal, T.J. Martin, and B.S. Gill. 1991. Identification of alien chromatin specifying resistance to wheat streak mosaic and greenbug in wheat germplasm by C-banding and in situ hybridization. Theor. Appl. Genet. 81:381-389.

French, R., and D.C. Stenger. 2003. Evolution of wheat streak mosaic virus: Dynamics of population growth within plants may explain limited variation. Annu. Rev. Phytopathol. 41:199-214.

Graybosch, R.A. 2001. Uneasy unions: Quality effects of rye chromatin transfers to wheat. J. Cereal Sci. 33:3-16.

Haley, S.D., T.J. Martin, J.S. Quick, D.L. Seifers, J.A. Stromberger, S.R. Clayshulte, B.L. Clifford, F.B. Peairs, J.B. Rudolph, J.J. Johnson, B.S. Gill, and B. Griebe. 2002. Registration of CO960293-2 wheat germplasm resistant to Wheat streak mosaic virus and Russian wheat aphid. Crop Sci. 42:1381-1382.

Haley, S.D., J.S. Quick, J.J. Johnson, F.B. Peairs, J.A. Stromberger, S.R. Clayshulte, B.L. Clifford, J.B. Rudolph, B.W. Seabourn, O.K. Chung, Y. Jin, and J. Kolmer. 2005. Registration of 'Hatcher' wheat. Crop Sci. 45:2654-2655.

Li, H.J., M. Arterburn, S.S. Jones, and T.D. Murray. 2005. Resistance to eyespot of wheat, caused by Tapesia yallundae, derived from Thinopyrum intermedium homoeologous group 4 chromosomes. Theor. Appl. Genet. 111:932-940.

Mago, R., H.S. Bariana, I.S. Dundas, W. Spielmeyer, G.J. Lawrence, A.J. Pryor, and J.G. Ellis. 2005. Development of PCR markers for the selection of wheat stem rust resistance genes Sr24 and Sr26 in diverse wheat germplasm. Theor. Appl. Genet. 111:496-504.

Nagy, E.D., C. Eder, M. Molnar-Lang, and T. Lelley. 2003. Genetic mapping of sequence-specific PCR-based markers on the short arm of the 1BL.1RS wheat-rye translocation. Euphytica 132:243-250.

Payne, P.I., and G.J. Lawrence. 1983. Catalogue of alleles for the complex gene loci, Glu-A1, Glu-B1, and Glu-D1 which code for highmolecular weight subunits of glutenin in hexaploid wheat. Cereal Res. Commun. 11:29-35.

Peterson, R.F., A.B. Campbell, and A.E. Hannah. 1948. A diagrammatic scale for estimating rust intensity of leaves and stem of cereals. Can. J. Res. Sect. C 26:496-500.
Peterson, C.J. 1992. Similarities among test sites based on cultivar performance in the hard red winter wheat region. Crop Sci. 32:907-912.

Quick, J.S., J.A. Stromberger, S. Clayshulte, B. Clifford, J.J. Johnson, F.B. Peairs, J.B. Rudolph, and K. Lorenz. 2001. Registration of 'Prairie Red' wheat. Crop Sci. 41:1362-1363.

Roelfs, A.P., R.P. Singh, and E.E. Saari. 1992. Rust diseases of wheat: Concepts and methods of disease management. CIMMYT, Mexico, DF.

Saidi, A., and J.S. Quick. 1996. Inheritance and allelic relationships among Russian wheat aphid resistance genes in winter wheat. Crop Sci. 36:256-258.

Schwarzacher, T., and P. Heslop-Harrison. 2000. Practical in situ Hybridization. BIOS Scientific, Oxford, UK.

Seifers, D.L., T.J. Martin, T.L. Harvey, and B.S. Gill. 1995. Temperature sensitivity and efficacy of wheat streak mosaic virus resistance derived from Agropyron intermedium. Plant Dis. 79:1104-1106.

Seifers, D.L., T.J. Martin, T.L. Harvey, S. Haber, and S.D. Haley. 2006. Temperature sensitivity and efficacy of Wheat streak mosaic virus resistance derived from C0960293 wheat. Plant Dis. 90:623-628.

Seifers, D.L., T.J. Martin, T.L. Harvey, and S. Haber. 2007. Temperature-sensitive Wheat streak mosaic virus resistance Identified in KS03HW12 wheat. Plant Dis. 91:1029-1033.

Stakman, E.C., D.M. Steward, and W.Q. Loegering. 1962. Identification of physiologic races of Puccinia graminis var. tritici. USDA-ARS Bull. E-617. USDA, Washington, DC.

Talbert, L.E., P.L. Bruckner, L.Y. Smith, R. Sears, and T.J. Martin. 1996. Development of PCR markers linked to resistance to wheat streak mosaic virus in wheat. Theor. Appl. Genet. 93:463-467.

Vershinin, A., S. Svitashev, P.O. Gummeson, B. Salomon, R. Bothmer, R. Von, and T. Bryngelsson. 1994. Characterization of a family of tandemly repeated DNA sequences in Triticeae. Theor. Appl. Genet. 89:217-225.

Vogel, K.P., D. Tober, P.E. Reece, D.D. Baltensperger, G. Schuman, and R.A. Nicholson. 2005. Registration of 'Haymaker' intermediate wheatgrass. Crop Sci. 45:415-416.

Wells, D.G., R.S. Wong, C.L. Lay, W.S. Gardner, and G.W. Buchenau. 1973. Registration of CI 15092 and CI 15093 wheat germplasm. Crop Sci. 13:776.

Wells, D.G., R.S. Kota, H.S. Sandhu, W.S. Gardner, and K.F. Finney. 1982. Registration of one disomic substitution line and five translocation lines of winter wheat germplasm resistant to wheat streak mosaic virus. Crop Sci. 22:1277. 